University of Louisville

ThinkIR: The University of Louisville's Institutional Repository

Electronic Theses and Dissertations

$5-2004$

\title{
The tracks of my tears : an actor's account of her progression in the role of Jessie Cates in Marsha Norman's play "Night, Mother".
}

Kia Tomille Elizabeth Fisher

University of Louisville

Follow this and additional works at: https://ir.library.louisville.edu/etd

\section{Recommended Citation}

Fisher, Kia Tomille Elizabeth, "The tracks of my tears : an actor's account of her progression in the role of Jessie Cates in Marsha Norman's play "'Night, Mother"." (2004). Electronic Theses and Dissertations.

Paper 439.

https://doi.org/10.18297/etd/439

This Master's Thesis is brought to you for free and open access by ThinkIR: The University of Louisville's Institutional Repository. It has been accepted for inclusion in Electronic Theses and Dissertations by an authorized administrator of ThinkIR: The University of Louisville's Institutional Repository. This title appears here courtesy of the author, who has retained all other copyrights. For more information, please contact thinkir@louisville.edu. 
THE TRACKS OF MY TEARS:

AN ACTOR'S ACCOUNT OF HER PROGRESSION

IN THE ROLE OF JESSIE CATES IN

MARSHA NORMAN'S PLAY 'NIGHT, MOTHER

By

Kia Tomille Elizabeth Fisher

B.A., Clark Atlanta University, 2000

\begin{abstract}
A Thesis
Submitted to the Faculty of the

Graduate School of the University of Louisville

in Partial Fulfillment of the Requirements

for the Degree of
\end{abstract}

Master of Fine Arts

Department of Theatre Arts

University of Louisville

Louisville, Kentucky

May 2004 
Copyright 2004 by Kia Tomille Elizabeth Fisher

All rights reserved 
THE TRACKS OF MY TEARS:

AN ACTOR'S ACCOUNT OF HER PROGRESSION

IN THE ROLE OF JESSIE CATES IN

MARSHA NORMAN'S PLAY 'NIGHT, MOTHER

By

Kia Tomille Elizabeth Fisher

B.A., Clark Atlanta University, 2000

A Thesis Approved on

April 15, 2004

by the following Thesis Committee:

Dr. Lundeana Thomas, Thesis Director

Nefertiti Burton

Dr. Edna Ross 


\section{DEDICATION}

This thesis is dedicated to my Lord and Savior,

Jesus Christ,

whose love and grace

gave me comfort and support

during this amazing experience. 


\section{ACKNOWLEDGEMENTS}

Special thanks to Professor James Tompkins for having faith in my talent and granting me the opportunity to have such an amazing experience. Thank you to Dr. Lundeana Thomas for your encouragement and support throughout my graduate school process and especially as director of my thesis committee. Thanks to Professor Nefertiti Burton for serving on my thesis committee and facilitating such amazing and lifechanging experiences for me. Thanks to Dr. Edna Ross for your excitement and support and for being so willing to serve on my thesis committee.

Thank you to my classmates, Shawn Knight and Stacey Smith, for your love and support. I could not have picked a better class. Thank you to the entire faculty of the Theater Arts Department for all of the knowledge that you imparted. Thank you to Alice Childress for your maternal love, support, and kindness. You made my thesis play truly memorable. Thanks to the crew of 'night, Mother. All of the elements of the play came together to making an amazing show.

Thank you to Ms. Carol Mitchell-Leon for affecting my life with your motivation and encouraging thoughts and words. Many thanks to my parents, Ronald and Cheryl Fisher, and to my entire family for your continued support of all that I do and your unconditional love. 


\begin{abstract}
THE TRACKS OF MY TEARS:

AN ACTOR'S ACCOUNT OF HER PROGRESSION

IN THE ROLE OF JESSIE CATES IN

MARSHA NORMAN'S PLAY 'NIGHT, MOTHER
\end{abstract}

Kia Tomille Elizabeth Fisher

April 15, 2004

This thesis is the progression of the knowledge, skill, and insight of an actress in the Theater Arts Department as she was in pursuit of a Master of Fine Arts Degree. This knowledge, skill and insight culminated in the performance of the role of Jessie Cates from 'night, Mother by Marsha Norman. The character was analyzed from research in books, articles, documents, and websites. Research about depression and suicide also informed the actress to assist her in the characterization of the role.

A relationship in the play was developed by creating a personal relationship between the two actors. Exercises from voice and movement classes contributed to the performance. Challenges with the character included vocal projection, energy, status, and the understanding of the character's mental and emotional disorders. This thesis includes the actor's growth through class work, research, and performance. The entire experience served to build the confidence of the actress. 
TABLE OF CONTENTS

PAGE

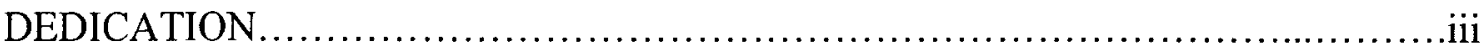

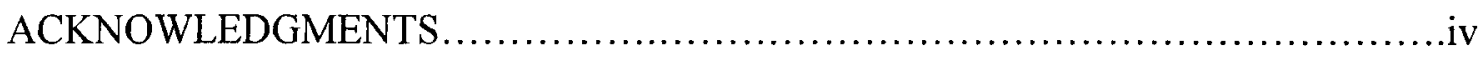

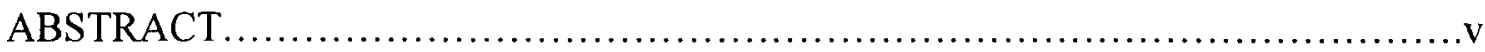

CHAPTER

I. INTRODUCTION - What am l looking for?....................................1

II. FINDING A THESIS - The search is on..............................12

III. RESEARCH - Understanding the source of the pain.....................21

IV. REHEARSAL - Working towards my goal..........................30

V. PERFORMANCE - Facing an altered reality ..........................37

VI. CONCLUSION - Drying the tears.................................43

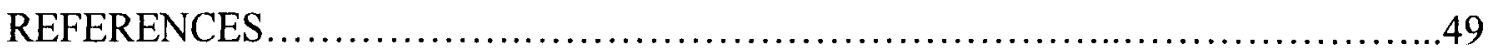

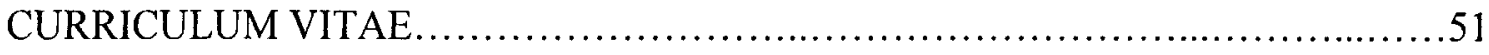




\section{CHAPTER I \\ INTRODUCTION - What am I looking for?}

Ever since I portrayed Suzy Snowflake in my preschool Christmas production at the tender age of three years old, I have wanted to pursue a career in acting. I never had a concrete reason why I wanted to act, except I felt a hunger inside that could only be fed when I was performing on a stage. My first encounter with a successful, professional actress happened when I was only ten years-old. I went to a seminar featuring my inspiration, Cicely Tyson, at the University of South Carolina in Columbia. I got to leave school early that day and my teacher was delighted to see me have this opportunity. I had seen Cicely Tyson on the television movie, The Autobiography of Ms. Jane Pitman. She mastered the portrayal of the title role from age sixteen until well over age one hundred. As an aspiring actress, I instantly knew that she was an inspiration for me because of her amazing performance ability. I wanted to do whatever it took to be a successful actress like Cicely Tyson. Through successful training and gaining understanding of the text, I planned to successfully exhibit my knowledge of acting with my thesis role of Jessie Cates in Marsha Norman's play, 'night, Mother. My goal was to obtain more confidence in my acting by achieving range and volume in my voice as well as fluidity and comfort in my body.

Desire for knowledge about acting originally came from the sentiments of Cicely Tyson on the day I met her when I was in the fifth grade. After the seminar, she gave me 
an autograph (mostly because I was one of the only children in attendance at the seminar.)

I told her that I was an aspiring actress, and she told me to keep working and go to school to learn my craft. She also wrote a message to me telling me to follow my dreams. I knew that I had to go to college and major in theater arts to actively pursue a career in acting.

After receiving a Bachelor of Arts in Theater from Clark Atlanta University (CAU), I still did not feel qualified to pursue a career in acting. I knew that there was more for me to learn so I set my sights on graduate school. I was first introduced to the Theater Arts Department at the University of Louisville (U of L) when Dr. Lundeana Thomas came to CAU to recruit African American students to build the African American Theatre Program (AATP). Though I was a graduating senior at CAU at the time of recruitment and interested in attending graduate school, $\mathrm{I}$ had never considered $\mathrm{U}$ of L until then. A group of students from CAU had already gone to the Unified Residential Theater Auditions (URTA,) auditioning before a group of theater schools. Collectively, we did not do well, individually, I did okay. None of the schools that were possibilities for me were of interest to me. I attended several other unified auditions to look for possible job opportunities upon graduation.

I became more interested in $U$ of $L$ after my friend, Dorothy Bell, was the first to receive an offer. As she was considering $\mathrm{U}$ of $\mathrm{L}, \mathrm{I}$ learned more about what they offered in the way of scholarship monies and it began to sound more and more appealing to me. I patiently waited for a reply and learned that several others from Clark Atlanta had been accepted to the University of Louisville. I learned from a telephone call from Dr. Thomas that there was no room for me in the incoming first-year graduate theater class. 
Therefore, I accepted a job for which I had auditioned at another unified audition. In August of 2000, I moved to St. Paul, Minnesota to start my new job as an actor/educator with a touring children's theater company, C.L.I.M.B. Theatre, was an acronym for Creative Learning Ideas for Mind and Body.

According to their website, the motto at C.L.I.M.B. is, "Teachers, we will help you; students, we will teach you; and actors, we will grow you." When I left, I commented that I did not feel like the company grew me. There was no effort on their part to grow me. The growth that I experienced while I was there came from what I gained from my own experiences. I also feel that I much of what I gained from graduate school has been from the lessons that I have learned through various experiences. I have learned a lot since I have been here. I also know that my personal growth is off the scales. I hated my time in Minnesota, so by January, I again started to pursue the prospect of furthering my education at the University of Louisville.

I visited with friends who were then first-year graduate students at $U$ of $L$. They were cautionary and asked me to re-consider if I was willing to deal with a totally different type of faculty than were at CAU. The faculty at CAU was very nurturing and tried to help the students reach their goals by personally taking an active interest in each of the students. They each personally worked with each student to improve the students' short-comings. I realized that $\mathrm{U}$ of $\mathrm{L}$ was different from $\mathrm{CAU}$ after viewing an unusual play, visiting a rambunctious Acting for non-majors class, and auditioning for a department where one of the faculty members who should have conducted the audition did not even appear. Although, I learned fairly soon that I had been accepted, I still had 
to wait impatiently for my contract to arrive in the mail. I finally received it the summer before I was to enroll in graduate school.

As I started my journey at the University of Louisville, I did not know what to expect. My only desire from the theater department was to help me grow in every possible way. I knew that I needed to learn to project my words with vocal volume, but I did not know what acting problems I had or how to recognize them. I believe the classes that I took in the first semester of my first year at $\mathrm{U}$ of $\mathrm{L}$ allowed me to recognize acting issues that I would spend time working on for the next three years.

Our classes consisted of the three first-year graduate students and several undergraduate students. I often wondered what made the graduate school here any different than undergraduate school because undergraduates could enroll in some of our graduate classes. I had a hard time getting started because I learned that I had not been officially accepted into the school. I was starting to feel like this experience in graduate school was not going to be easy and that I would always have to work hard to get what I wanted and needed. When I felt like others were against me, I knew that I had to find my help in God. I found a church in town and close to where I lived. I started to attend St. Stephen's Church. The minister, Reverend Kevin Cosby, always said something that I took as a personal motto: "I am like a teabag, you never know how strong I am until you put me into hot water." That motto would be tested over and over again at the University of Louisville.

My first semester in voice class brought out a huge challenge to test my strength. I could not breathe. I especially could not breathe when I got excited. I would have dreams where I would cry uncontrollably and could not talk. I felt humbled when I tried 
to open myself to the activities the instructor had us do to find our inner child and open our breath.

My humility, sensitivity, and naiveté were misinterpreted by my professor, Dr. Frye, as childishness. I would spend the rest of my tenure trying to dispel that myth to her. She admitted this was her impression of me well into the first semester of my third year. I was fighting an issue with her and other faculty members that I did not know existed. I continued to get cast in childlike roles in plays, the repertory company and in acting classes. I did not do these roles well, or I did them too well, because soon, this was how Kia was being perceived.

I now realize that there is a distinct difference between childishness and childlike qualities. Though I disagree with being childish, I did acknowledge in my first semester in voice class that I found that my internal voice was quite childlike. I wrote of my internal voice in a journal on September 1, 2001, "It always wants to do and say the right things to please everyone. It is hurt when the right things are not done or said to me. It is more hurt when the wrong things are done or said to me. It is selfish and cries a lot. It will not let go of old bad habits." Writing these words early in my graduate career helped me start to look at one of my major acting problems. My desire to please others hindered my own process of finding truth in a character.

By the $20^{\text {th }}$ of September, I wrote in my voice journal that I had learned to speak in my full voice through my tears. I had a dream the night before that I was sobbing and could not communicate. This dream scared me because I felt like I could not tell others how I was feeling while I was crying. I actually cried that same week in voice class and was reassured that I could talk through my tears. I was still able to communicate some of 
my problems. It also excited me that I was able to dry my tears and not worry that I was crying when I did my monologue. I immediately began to work through this newly surfaced acting challenge. Facing my emotions and emotionally gaining control of my voice was especially difficult when my emotions seemed out of control.

I did my monologue for the voice class on September $25^{\text {th }}$. I learned from my teacher not to restrict myself. During the critique session which followed, I learned to take in my audience by glancing at them while parting my lips. After the monologue, I mainly learned breath is the speaker's most important tool. I found the more I enjoyed my monologue and my audience, the more my audience would enjoy my monologue and me. At that time, I was still learning not to hold my breath and just breathe. The process of learning to breathe correctly reminds me of the movie, Waiting to Exhale by Toni Morrison, where women are depicted as creatures that hold their breath until they find the love of their lives. My friends and I decided that we would create the sequel to Waiting to Exhale where we would not let life stress us. We would entitle our movie, Breathe Bitch!

My voice instructor taught me a valuable lesson about my breathing. After I complemented myself for maintaining my breath during a short role in my first production at $\mathrm{U}$ of $\mathrm{L}, \mathrm{Dr}$. Frye reminded me that I should get into the habit of using breath all of the time. I realized that I could breathe well only when I stayed calm. I became conscious of my breathing. I knew when I was not breathing, but I could not always gain control of my breath. Dr. Frye challenged me to change this on stage and in life. She reminded me that I must learn to continue emotion and breathe simultaneously. 
Calming myself down with my breath would not help me if I had to play a character who was upset.

My breathing made huge strides by the end of my first semester. Both my voice and body did things that I never fathomed. I was ecstatic to know the beginning of my journey as a graduate student started so well and it was only the beginning. At the end of the first semester, I decided to do a studio show. I played a mentally insane woman who was hallucinating about the religious views forced on her as a child. I found that internalizing insanity helped me to develop the character better. The heavy breathing that helped to define the role was totally controlled and part of the character. The auto-drama (an autobiographical, one-person show) that I did in acting class was quite emotional for me though the subject was a bit light-hearted. I fought to breathe as I performed. I was also proud of my first monologue in voice class. I took many risks with my breath that I would never have done before, yet I still recognized that I had room left to grow.

My breathing is not a huge problem any more. I have rarely caught myself holding my breath since then. When I do catch myself, it is during extemporaneous speech. It is rare then as well, though. I constantly reminded myself to breath. Breathing helps to calm me down. Even when I cry, I am still able to talk when necessary. Ultimately, controlling my breath allows me to maintain a full voice using breath from the diaphragm. This control makes my voice richer and stronger. I am now able to reach higher and lower registers in my voice and create different kinds of voices for different characters.

I also learned to create different characters with my posture and body movements. Movement class taught me how to do this. However, movement class annoyed me 
because I did not want to sit still long enough in any space to truly find my grace and move with ease. Professor James Tompkins, my movement instructor, saw the challenges that I faced. I tried too hard to get everything "right" and to be what I thought the faculty expected of the perfect student. I often felt fidgety and instead of giving in to my instincts, I began to look uncomfortable on stage. Eventually, movement class taught me not only to be cautious of how I moved, but also to be free from my body.

As a first-year graduate student, my first big assignment in an acting class was the auto-drama. Professor Nefertiti Burton, my acting instructor, gave the class an opportunity to share, as actors, a piece of ourselves and our lives to our classmates. I think the purpose of the exercise was to open up and then be able to share more of ourselves on stage in the long run. This assignment was my first failure as a graduate student. Having just moved to a new city, started a new school, and was now in a class with strangers, I was expected to disclose a private part of myself and share it with this class of strangers. I struggled with this dilemma. Should I open up to the class and give the audience part of me to possibly become a better actor or should I keep quiet and not let others find out who I really am? Instead of these two alternatives, I learned to create a character of myself to appease my professors. Later, I would embellish events in my life to make my class performances more dramatic. For instance, for our movement final, I performed a piece about date rape. Much of the monologue was contrived. I felt like my life was not exciting enough to express myself in class. Though it still does not seem fair, I know now that as an actor (at least as the actor that I am expected to be in this department,) I must find parts of my own reality to bring to the stage. I must also create a realistic fictional demeanor to have a dramatic effect for the audience. I feel now that 
acting can best be done when you can find a state that you have never been in personally. One does not have to overcome horrible experiences to become a good actor.

In retrospect, I loved doing and seeing the auto-dramas because it allowed me to revisit some things that happened in my past. I know that it was hard for most of the people in my class (myself included) to discuss deep issues in our lives to people who may or may not be our friends, but just happen to be in our class. I do, however, appreciate that there were different moods to all of the pieces. All of them seemed well planned, developed, and performed. Though I often had to draw on personal experiences to participate in many of my classes, the only thing that I learned from this type of exercise was to create an untrue reality for myself.

I was a nervous wreck in anticipation of my auto-drama. Once it was done, I felt fine about it and happy to know that others enjoyed it. As with most performances, I found a million things I could have done better. Though my grade for this presentation was above average, another hard lesson that took most of my matriculation to learn was that though I worked just as hard or harder than someone else, my evaluation would often reflect a lesser grade. This is a great lesson for life. I would come to realize that most of my hard work was often in vain and when I work from my passion instead of working to please the instructor, I would usually be more satisfied with the performance (and sometimes the grade.) I still needed to learn that my assignments were for my benefit and not the professors' benefit. When I worked to please others, they were usually not pleased, though I would be. When I only cared about myself and the piece, the work showed and the professors would be pleased. 
At times, I felt I had become a worse actor than when I came here, at least before, I was more confident in my acting. I think I will better understand how my time in graduate school has affected my acting after I am physically separated from the school for a few years. I constantly felt like my professors did not believe that I could do something before I even attempted it. Ultimately, knowing that the faculty did not believe in me empowered me to believe more in myself. However, the feeling of apathy from the department about my success was really hurtful. What is the purpose of an educational environment if it is not to give students a forum to try new and different things? I was often told everything that was wrong with my performance, but I was not told how to correct it. The movement class was based in this teaching theory. Professor Tompkins would often tell us a performance was not aesthetically appealing. We then figured out, on our own, how to make the performance better. Sometimes, our class could not get to the gist of the lesson because we only dwelled in our defeat. However, in some instances, this technique can be very helpful. I think that it is important for me to learn how to correct my own mistakes.

As a graduate student, I figured out how to correct most of my own problems. I went into my thesis performance with two concerns. I wanted to find the physical stature of a middle aged, depressed woman. Often, I was cast as a juvenile lead. My thesis would give me a new physical challenge. I also worked on speaking on my voice with strength through vulnerability, without going into a higher speaking register. My thesis would be a new challenge for me at $\mathrm{U}$ of $\mathrm{L}$. I took the challenge of this thesis as I did with every challenge as an actor. As I begin the final heat of the journey through graduate school, I was reminded of the old, Negro spiritual, "I don't feel No Ways 
Tired." It says, "I just can't give up now. I've come too far from where I started from. Nobody told me that the road would be easy. I don't believe HE brought me this far to leave me." The "HE" in the song refers to GOD. I know God brought me through the rough road of graduate school.

I must confess that from portraying Suzy Snowflake to "learning my craft" as suggested by Cicely Tyson provided a greater challenge than I anticipated. I did not know that $\mathrm{U}$ of $\mathrm{L}$ and $\mathrm{I}$ were the right choice for each other. But, I made an investment of time and energy so that I was prepared to make my choice of schools work and leave here with a Master of Fine Arts degree. The next requirement was the thesis role and I prepared myself to find one that would serve to teach me more about myself and about my craft. 


\section{CHAPTER II \\ FINDING A THESIS ROLE - The search is on}

The process of finding my thesis role was extremely hard. The search came after the fallout of the previous semester when I was threatened with losing my status as a graduate student. I went to the entire undecided faculty with interest in finding a thesis role. I instantly got the impression that none of the professors wanted to commit to directing my thesis show. I know that I could do any role if given the opportunity because I am an actress, so I know that I will work to make any show successful. I planned to find a role with substance and use the depth of such a thesis role to learn and grow.

The role of Jessie in 'night, Mother by Marsha Norman was the role that I needed to prove my worth to the department. My thesis journey started on a Wednesday night with auditions for the woman who would play the role of my mother. Over twenty ladies auditioned and most were good, yet none stood out to me as perfect. I knew that age would be an issue, but I also wanted an African American mother. Professor Tompkins said he saw that I seemed most comfortable with an African American mother. I was more natural and confident when paired with another woman of the same race. He also saw me becoming more comfortable with the role throughout the audition night. I was happy that I would gain more comfort in rehearsal that would last through the course of three months. 
He also told me that my voice pitch changed depending on with whom I was paired. I became conscious of this issue. I used the vocal techniques that I learned in voice class to change my voice during rehearsals. I would warm up with a vocal scale. This would allow me to find my middle vocal range and stay there. However, during auditions, I recognized that voice would be a major issue for me to conquer throughout the rehearsal process.

At one point, I traded roles with one of the other ladies who auditioned. This gave me insight into Thelma (the mother.) I wanted an African American mother to help me tap into the insight that I had found in the play. The two characters had an intense relationship and shared many of the same life experiences. With an understanding of both characters, I then wanted an African American mother with whom to interact. Since my own mother was African American, I felt I could relate better with an African American mother in the play. I now know that this was wrong because another race could add new dynamics that I had not yet considered.

The age of the character was a huge issue. We needed a seasoned actress who could also carry half of the play as well as look motherly and act motherly. I thought students would learn the most from the experience of performing in this play and requested that the actress be a student at $U$ of $\mathrm{L}$. Alice Childress, a continuing education student, won the role and was thrilled. Though I had wanted an African American mother, Alice, a white woman, appeared to be the best choice. I initiated a relationship with her both on and off stage. Soon, she became Jessie's mother to me. Having Alice in the role of Thelma allowed me to create a back-story about Jessie's African American father and about the crucial added issue of Jessie's racial identity. Now, Jessie has had to deal with being bi-racial all of her life as well. Jessie's parents' ethnic, 
cultural, and racial differences added to the tension in the family. This tension would give the character depth. Doing a character analysis created more depth to the play for me.

The other main-stage plays that I had done had not helped me create a complex character, mainly because I was cast in small roles for the other main-stage productions. I was a reporter in an adaptation of Julius Caesar during my first semester at $\mathrm{U}$ of L. Though I had more stage time in my second production, Trane: Beyond the Blues, none of the various roles that I portrayed in the episodic play had a clear through line to analyze. In Bee Luther Hatchee, I appeared on stage for about five minutes as the main character's estranged mother. I also appeared behind a scrim, so the audience only saw a shadow of my body and could not see any expression on my face. I played a maid in Firebugs, my last main-stage play before my thesis performance. This play was the longest that I appeared as the same character. However, I only came on stage to serve the family and guests. Playing such a stereotypical role taught me that I have the confidence to portray a maid with the dignity that a servant deserves.

Confidence was an attribute that came as a result of the challenges faced in my classes. I had to gain confidence to perform in front of my acting classes to receive the desired grade. Sometimes in acting class, we, as actors in the scene, did not know how to fix the scene without the outside eye of a director. I often blamed a director or a lack of a director when acting projects did not go as well as I would have wanted. In plays, a director's different concept would hinder the performance that I envisioned for my character. I realized that though a director should make a performance better, as an actor I had to give my best performance and take responsibility for it. Professor Tompkins said to me for the first time during rehearsal for Fire Bugs that many brilliant actors do not perform well with different directors. I felt like he was referring to me. Though it seemed like he had no malice intent with this comment, I was insulted. 
I felt like he was telling me that my performances had not been good until then, because I had not worked well with my former directors. He repeated this philosophy several times during rehearsal for 'night, Mother. Though it might be true, I should hope that I have learned to portray the appropriate image during auditions so that I will be appropriately cast. I also know that I must be able to work with any type of director if I plan to get work, I should be able to produce the desired work with anyone as my director.

Working with someone who had not been my first choice as a director would also be a good challenge for me. I could find the truth in the character for myself and see if my work could be enough if the director's ideas did not lead to a well-thought out concept. 'night, Mother resonated with me when I first read it as an assignment in the Play-script Analysis class lead by the department chairperson, Dr. Russell Vandenbroucke. My initial response was one I had to fight throughout the rehearsal process, I mostly identified with the mother. Of the two characters in the play, I felt like I could best play her. I cannot imagine any murder being justifiable and I think that the worst pain of a parent is to lose a child. I never want to deal with the suicide of a person I love. For, I would not like to see someone I care about kill themselves. It was not until the performances that I became completely absorbed in the ideals of Jessie and did not stop to think about Thelma's point of view rather than Jessie's will. Finding this selfish viewpoint was especially helpful in forming the character because the character ultimately sided with her own selfishness to complete her murder. This provided the opportunity to remove Kia Fisher to make room for Jessie Cates; her feelings, her ideas, and her choices.

I learned a little about forming a character from a book I often referenced during the rehearsal process. A Practical Handbook for the Actor by Melissa Bruder, Lee Michael Cohn, Madeleine Olnek, Nathaniel Pollack, Robert Previto, and Scott Zigler was a text for my Acting 
Workshop Class lead by Professor Nefertiti Burton. I was first introduced to this book in Gary Yates' upper level acting class at Spelman College. I hated the book because it seemed boring and simplistic. However, I continued to find more use for this book that I had ever imagined in Jennifer Hubbard's class in my second year of graduate school. The book would be particularly interesting to a student who has not gone beyond a basic level acting class. After the third time reading it, I realized that any good acting teacher should teach every major point in that book. The book is so simple that it seems most useful for an actor who is studying on his/her own, without a teacher. The only thing that continues to be helpful to me, even in a thesis role, is the book's core thoughts on analyzing a scene. An actor should ask him/herself three questions:

1. What is the character literally doing?

2. What is the essential action of what the character is doing in this scene?

3. What is that action like to me? It's as if...(19)

I considered that my one-act thesis play always seemed to me like a long scene; so I was able to use these questions to analyze "the scene." Jessie cleans and organizes the house and informs her mother of how things operate in their house on a daily basis. Essentially, Jessie was preparing the house and her mother for life after Jessie's death. The last question required that the actor find a way to parallel her character's action with something that may actually happen in her own life: "It's as if" I am training the replacement for my job.

I started my portrayal of Jessie's characterization by following Marsha Norman's depiction of Jessie in the character summary listed in the playbook before the script. Norman describes Jessie as in her thirties and "vaguely unsteady, physically" (4.) Normans says, "It is only in the last year that Jessie has gained control of her mind and body, and tonight, she is determined to hold on to that control" (4.) Norman goes further to expound upon the relationship between Jessie and her mother, Thelma: 
As a rule, Jessie doesn't feel much like talking. Other people have rarely found her quirky sense of humor amusing. She has a peaceful energy on this night, a sense of purpose, but is clearly aware of the time passing moment by moment. Oddly enough, Jessie has never been as communicative or as enjoyable as she is on this evening, but we must know she has not always been this way. There is a familiarity between these two women that comes from having lived together for a long time. There is shorthand to the talk and a sense of routine comfort to the way they relate to each other physically. Naturally, there are also routine aggravations. (4)

I read the proceeding paragraph over and over before I attempted to tackle the role in rehearsal. I finally decided that the hardest part would be establishing an on-stage connection with Alice, the actress portraying Thelma. I realized that the only way I could even attempt this bond was to make it real. Alice and I spent lots of time talking, going out to eat, and just being in one another's company.

I formed a bond with Alice and she still serves as a maternal figure in my life. I translated many of my feelings for her to her character. I better understood Jessie based on what she says to her mother and how she talks about herself. She makes her ideas about herself, her depression, and suicide fairly clear. Toward the beginning of the play, 'night, Mother, Jessie gives the audience some insight as to why she acts the way she does, how she feels, and what brought her to this place in her life. In the script, Jessie reminds Thelma, "You know I can't work. I can't do anything. I've never been around people my whole life except when I went to the hospital. I could have a seizure any time. What good would a job do? The kind of job I could get would make me feel worse" (26.) Jessie knows that the only way to relieve herself from her boring life of depression is to end her own life now. She stopped caring about finding a way to feel better. Jessie's words show her apathy for life.

Thelma's words also say a lot about Jessie. I was able to concentrate more on the character's lines and what they meant the night Alice, my scene partner, was sick and could not 
come to rehearsal. After several failed attempts to contact Professor Tompkins by phone and email about the fate of rehearsal (I was hoping he would cancel it because I was tired,) I went to the school. Professor Tompkins and I, reluctantly, decided to continue with rehearsal. My reluctance soon faded as we were able to accomplish a great deal. This rehearsal reminded me of how Dr. Vandenbroucke taught us how to decipher a character. According to Dr. Vandenbroucke, the reader of a play knows about the character "based on what the playwright says about the character, what the character says about herself, and what others say about the character." By now, I comprehended what Jessie said about herself and what the playwright said about Jessie. At this rehearsal, I would understand how to analyze my character based on what another character says about her. During rehearsal I would proceed with the blocking responding to the assistant stage manager. It was actually a blessing in disguise. I was able to take my time and feel out the lines. I did not have another actress there looking for my attention. This made me realize how much undeserving attention I had been giving her character. Though most all of the lines are to my on-stage mother, I did not need to address her directly, eye-to-eye.

I also reexamined much of my character and some of the lines in 'night, Mother. Jessie's mother, Thelma, has a friend named Agnes. In the script, when Jessie asks Thelma why Agnes will not come by the house to visit, Thelma recalls, "She says your hands are cold" (30.) It was not until this night without Alice that I realized that my hands are cold. Professor Tompkins told me several things that he always does to get his cold hands warm. I always have cold hands too, so I knew that I had to do some of those things I do to warm my hands on stage. I began to add hand rubbing and arm folding to the character. Examining the text allowed me to analyze my character in several ways. 
After teaching two semesters of Acting for non-majors, I also examined the character in the same way I teach my students to analyze characters. This GOTE sheet analysis is from Robert Cohen's Acting One. GOTE is an acronym for:

1. Goals

2. Other (obstacle)

3. Tactics

4. Expectation (51.)

Cohen says, "GOTE, therefore, represents a basic method for approaching an acting assignment" (51.) A GOTE sheet separates specific points that will develop a complete character when combined in performance. Cohen also writes, "Goal is the character's principal quest, which the actor assumes" (51.) Jessie's quest was to prepare Thelma for Jessie's suicide and subsequent life without her. As the actor, I accepted this quest and believe that I succeeded.

The second concept of GOTE is other. Other is the next point that Cohen expects an actor to develop for her character. According to Cohen, "The other is the scene, therefore, is what makes achieving goals difficult. Often the other is your chief obstacle: another ' $\mathrm{O}$ ' word. The struggle to overcome obstacles - particularly when those obstacles are other persons and other person's pursuit of their goals - creates much of the dynamics of acting, the work of acting" (52.) Jessie's mother embodies the other obstacle for Jessie. Though Jessie has resigned to commit suicide before the play even starts, she must dodge the relentless efforts of her mother to stop Jessie's execution. Jessie's mother, Thelma, will do everything in a mother's power to stop the death from happening. It is the idea that the mother and daughter are each other's obstacles which engages the audience. They must use different tactics, changing when necessary, to 
obtain their own goal by getting past each new tactic that the other person uses as an obstacle.

Robert Cohen describes, in Acting One, that tactics are; "the character's means of trying to achieve goals" (35.) Jessie's tactics included calmness, force, focus, and sincerity. Attempting to achieve the goal through these tactics made Jessie real to me. I started using tactics once we began the blocking (designing the movements) for the first scene. Once I started using tactics, I could feel when I needed to fluidly transition to a new tactic. Sometimes, I felt stuck in a tactic that was not working and I could not figure out how to change tactics. Ultimately, Jessie wanted to win the argument with her mother and prove that she had made a good decision. Jessie's calmness would instantly turn to rage to get an answer from her mother, even if it was an answer Jessie was not prepared to hear.

The final part of this analysis method was expectation. Expectation "gives tone, spring, and excitement to the dramatic pursuit of goals and quest for victory. It also lends every dramatic action at least a touch of enthusiasm, which can prove deliciously infectious" (43.) Expectation adds color and intrigue to the piece. Jessie knows that whether her mother likes it or not, Jessie is killing herself tonight. Jessie has made this decision long before now and she plans to stick with it. She is excited that the night has finally come and there is nothing Thelma can do to change things.

I wanted a thesis role in an African American play as an African American character with an African American director. I had pictured things another way. Although I had unfulfilled desires, I was more than satisfied with the director, the play, the character, and my cast partner. Now I was ready to begin the research to understand the source of Jessie's pain. 


\section{CHAPTER III}

\section{RESEARCH - Understanding the source of the pain}

The summer before my thesis performance, I found a psychology text book, Psychology by Lester A. Lefton. I searched for the word suicide in the index to find my first bit of research for the play. The following sentences would be the first thing that stood out to me:

Attempters try to commit suicide but are unsuccessful. They tend to be young, more often women, impulsive, and more likely to make nonfatal attempts, such as wrist slashing. Completers succeed in taking their lives. They tend to be male and older, and they use lethal techniques of self-destruction, such as handguns(480.)

After first reading 'night, Mother, I knew that Jessie was not the typical suicidal victim. As a Black female, my portrayal of Jessie made her even less typical. Jessie admits to considering suicide for at least ten years. This was not something that she decided on the spur of the moment. She is a thirty-five year-old woman who has had a long time to consider her life, and knows that using a handgun will allow her to succeed in her plan. Jessie's symptoms of depression and suicidal tendencies are common for suicide completers. Jessie is not the typical victim who lets her circumstances control her. Jessie knows how she has been feeling and how her life has been. She also knows the best choice for her. I gained knowledge of Jessie's mental state from research about suicide and depression. Marsha Norman's life experiences as well as my own life experiences also 
contributed to my depiction of Jessie. This chapter will focus on my research of mental health, Marsha Norman, and my own bout with depression.

Jessie has several elements that contributed to her suicide, including race and gender. Jessie's problems with lack of self esteem were established early in her life. Jessie's social ineptness probably peak during the especial difficult, developmental years of adolescence. As a Black woman, I had a hard time understanding how another African American can commit suicide. Alvin Poussaint, M.D., renowned Harvard psychiatrist, discusses this misperception in an article entitled, "Suicide Among Blacks" on HealthyPlace.com. Doctor Poussaint says, "Blacks pride themselves on being strong after surviving 250 years of slavery and years of segregation and discrimination. Depression, then, is seen as a sign of weakness." Depression does exist in the Black community, especially among Black women. I found more information on this subject on blackwomenshealth.com. It states that:

Mental health professionals estimate that clinical depression affects 17-20 million Americans a year. Untreated depression is second only to heart disease in causing lost work days in America, and it is the No. 1 cause of suicide. Depression strikes women - favoring no single ethnic group - at twice the rate of men. The good news is that once identified, more than 80 percent of people with depression are successfully treated. But many African-American women do not get treated, often because of a widespread belief in the African American community that depression is evidence of personal weakness, not a legitimate health problem.

According to the story entitled, "Teens, Race, and Stress," on CBSNews.com, young people of mixed race (those who describe themselves as black and white) have a higher risk of stress-related heath problems like feeling depressed.

Though her race and gender combat the likelihood that Jessie will be successful with her suicide, she has several elements that contribute to her suicidal behavior. 
Psychology, by Lester A. Lefton assesses that, "More than three times as many men as women actually succeed in ending their lives, although four times as many women attempt to do so" (480.) Also due to Jessie's divorce, mental disorder, and depression, her chances of committing suicide increase, for Lefton further assesses that, "The elderly, the divorced, and former patients with psychological disorders have a higher likelihood than others of attempting and committing suicide" (480-491.) Jessie has many factors that contribute to her suicidal depression.

Both Jessie and her mother have noticed a change in Jessie's behavior within the last year. Physically and emotionally, Jessie is to be recovering. Her outlook on life seems to be brighter. Now, she seems to be attempting to prove that she has a better attitude. She announces to her mother in the script of 'night, Mother, "I'm feeling as good as I ever felt in my life. I'm even feeling like worrying or getting mad and I'm not afraid it will start a fit if I do" (Norman, 44.) The fact that Jessie makes this statement and still kills herself is in accordance with another assessment by Lefton in Psychology:

People who have been suffering from depression are more likely to attempt suicide while they are recovering, when their energy level is higher. At the depths of depression, a person is usually too weak, divided, and lacking in energy to commit suicide. Although only 15 percent of depressed people are suicidal, most suicide-prone individuals are depressed" (481.)

I never thought about the dynamics of suicide. This was the first play that gave the suicidal person the chance to tell why she is committing suicide through her own voice and not a note. Jessie decided to wait until she felt better about her life. This decision seems to be thought out brilliantly. She is now surer about her decision and is not acting in haste, but is moving expeditiously toward her goal. She also now has the mental strength to make and carry out such a huge decision. 
My next concern was epilepsy. I wanted to know what it meant and how it could affect the quality of a person's life. Epilepsy would not allow Jessie to work or leave the house; the family seemed ashamed of it. Jessie appeared to be anti-social because of it. Thelma was so ashamed of it, that she never told her child, Jessie, that she was epileptic. According to John M. Freeman, M.D.; Eileen P.G.Vining, M.D.; and Diana J. Pillas, the writers of Seizures and Epilepsy in Childhood: A Guide for Parents, advise parents to, "Be truthful and be simple. What you should tell your child depends on your child's age, sophistication, and level of understanding. It is always best to be truthful. Otherwise, sooner or later you get trapped in a web of lies and cover-ups that will only make things worse (197.) Once I realized the relevance of Jessie's epilepsy, I looked for information on the subject. Finding the issues of children with epilepsy and their parents would help me understand a factor of Jessie's childhood and even her more recent past.

One out of every one hundred children has seizures, which is an electrical disturbance in the brain that makes the body move and jerk suddenly. A person cannot control his/her movements during a seizure. Sometimes, he/she may not know what is happening during a seizure and may lose awareness of what is going on and where they are. Epilepsy is a disorder of the central nervous system that causes a person to have repeated seizures at any time. Seizures are not always caused by epilepsy, but a person is considered to have epilepsy if she/he has more than one seizure (42.)

Like Thelma says in the play, doctors do not always know what causes epilepsy. Thelma says that Jessie inherited the disability from her father. This is possible, because sometimes epilepsy is inherited. Thelma also is concerned that Jessie's epilepsy may have come from something Thelma did, like dropping Jessie when she was a baby. This 
is also possible because head injuries can affect the brain and cause epilepsy as well. There is no cure for epilepsy, but it is treated with medication. Jessie, like most people with the disability, takes Phenobarbital products for her epilepsy. Researchers have found medications used to prevent seizures are cognitive-dulling. This may account for Jessie's lack-luster behavior.

If Jessie's epilepsy did stem from brain trauma, this might account for other emotional problems. Physical impairments from brain trauma include headaches, seizure disorders, as well as balance impairments. Cognitive impairments include short and long-term memory deficit, impaired concentration, slowness of thinking, and limited attention span. Slow thinking, lack of concentration, and low attention span all seem to be characteristics of Jessie. Other cognitive learning impairments include problems with reading and writing skills and planning. All of the psycho-social, behavioral, and emotional impairments related to brain trauma seem to fit the personality of Jessie. They include: fatigue, denial, self-centeredness, depression, sexual dysfunction, lowered selfesteem, lack of motivation, inability to cope, agitation, anxiety, restlessness, difficulty with emotional control, mood swings, excessive laughing or crying, inability to selfmonitor, and difficulty relating to others (223-238.)

Norman explains that the inspiration for her plays has always been from what she calls: her own "emotional memories." These memories that Norman had are shown in the deep loneliness that Jessie experiences though she lives with her mother. As a child, Norman admits that she was lonely. Coping with a solitary childhood resulting from the religious views of her strict, fundamentalist Methodist parents is what motivated Norman to become a writer. Her mother did not allow young Marsha to play with other children 
or watch movies and television. Possibly, Norman's experience with her own controlling mother allowed her to write such a controlling mother for Jessie in "night, Mother. The audience finds out that Thelma, Jessie's mother, has lied to Jessie about many things. Thelma has kept secrets from Jessie and expects Jessie to take care of everything in their house. Thelma even picked out a husband for Jessie. Understanding Marsha Norman's life, helped to understand Jessie's life.

Like Jessie, her character in "night, Mother, Marsha Norman had a concern with a life-threatening illness. Through the course of the play, the audience finds out that Jessie may have had epilepsy all of her life and that she has not had a seizure in over a year. Norman learned from a doctor that what she thought was just the flu was actually lung cancer. She was told that she had only a couple of years left to live. Norman, who had never been sick before this diagnosis, found out years later that she was not dying. The doctor had been looking at the wrong X-rays. Though death was no longer real, the threat of death had taken its toll.

This confrontation with death allowed Marsha Norman to take a deep consideration of the concept about death. In Newsday, an article by Blake Green entitled, "Feeling 'Blue'/ Playwright speaks ill, and well, of her new show," Norman elaborates that, until her supposed illness she "had a kind of romantic idea of death" Marsha Norman says, "Like she (Jessie) says in 'night Mother, it was going to be dark and quiet. Then I arrived at the place where it was a real possibility." Norman also says that she "realized I wasn't nearly attached enough to my life; I felt very disconnected from it (1.) This is the same type of disconnect that Jessie experiences in her life. She does not connect to the life that she lives, so she decides to totally remove herself from life. 
My play script analysis class taught me how to approach a script so that I connect to it as an actor. I learned that the nature of the character is found through what the character says about himself/herself, what other characters say about him/her, and what the playwright says about the character. I would use this way to better understand Jessie throughout the rehearsal process. In Chapter II, I discussed how I used what other characters said about Jessie to help me understand her. Now, I will discuss what the playwright says about the character. Marsha Norman explains the Jessie is "vaguely unsteady, physically." She "doesn't feel much like talking" "has a quirky since of humor" and "has a peaceful since of energy on this night, a sense of purpose" (4).

Jessie's quiet demeanor may have also come from Norman's life experiences. Norman not only played the piano, she also read books, and went to the theater as a child and Norman even had an imaginary friend. Jessie also does not have any friends nor does she leave the house. Jessie says in 'night, Mother, "I've never been around people my whole life, except when I was in the hospital" (26.) Norman says after her bout with death, "I realized how my mind had been playing with me. I was doing a lot of talking to myself. I became aware of how often I was lost in conversation with myself. I changed my life a lot by beginning to get my mind quiet." This seems to be Jessie's problem. Jessie had been thinking about killing herself "off and on ten years, on all the time since Christmas" (Norman, 22.) Now I also understood what Jessie says about herself. Jessie's mind could not calm down so she felt like she had to kill herself to find peace. Depression was the original source of my research. Once I obtained the role of a suicidal woman, I instantly thought back to my own battle with depression. Just a year before I received my thesis role, I was in the worst state of depression that I had during my entire life. Because of physical health issues, problems at school, and personal 
reasons, I began to see a counselor. I found myself inches away from being prescribed an anti-depressant. I went to St. Stephen's Church one Sunday and found information about depression. Attending church rescued me from my sadness; it would also eventually be useful to my research into depression.

The St. Stephen's Church bulletin of February 2, 2003 had several facts about depression:

- 1 out of every 8 Americans is suffering from depression.

- It is the \#1 emotional disorder.

- It's a feeling of helplessness and hopelessness that leads to intense sadness

- Some causes are medical, chemical and organic.

I realize as I look back at my Sunday service notes that though Jessie and I had the same symptoms, her outlook was different from mine. I knew that spiritual faith would be the only way out of the intenseness of my feeling and Jessie felt her only way out was suicide.

The sermon that Sunday concerned the story in The Bible of Elijah in 1st Kings: Chapter 19. Elijah was so depressed that he stayed in a cave until God called him out of the cave. As with Jessie, things for Elijah were looking down. Things always look worse than they really are. Like Elijah, I wanted to take action and uplift my own life. I too, took matters into my own hands without consulting the Lord and ended up alone and depressed in a cave. Unlike Elijah, who went out to the mountain to express his feelings, Jessie kept her feelings hidden inside. Jessie blamed herself for her depression and she also punished herself for those feelings about herself. It was not until I went to God to express my feelings that I understood Elijah.

Having these feelings helped me to identify with Jessie, but my faith in God seemed to make it harder for me to understand Jessie's choice. Spirituality was 
something that Jessie never considered. It is her mother, Thelma, who reminds Jessie that suicide is a sin. This helped me to realize that Jessie did not have the same values. I realized that my faith was what held me back from getting to Jessie's feelings; so that realization allowed me to know that spirituality was not an issue for Jessie. I, as the actor, had to give up my own beliefs for my character. I looked to God. On February 2, 2003, my pastor, Rev. Dr. Kevin W. Cosby said, "If you look within, you'll be depressed. When you look around, you'll be distressed. But when you look to God, you'll be blessed." Jessie looked within her and around her, but not to a higher power.

Researching for this play included finding sources on epilepsy in the library and finding sources on the playwright and the importance of race and gender in depression and suicide on the internet. I also referred to a church bulletin and notes that I kept on my own battle with depression. After having a clearer understanding of the major issues in the play, I was ready to begin the rehearsal process. 


\section{CHAPTER IV}

\section{REHEARSAL - Working Towards my Goal}

Rehearsal is an opportunity to bring the actors together to work collectively to formulate the director's concept. It allows actors time to modify their work until (in an optimal situation) the director and the actors are satisfied with the performance. The rehearsal process for 'night, Mother started with table work. Alice and I would sit at the table with the director and assistant stage manager. The assistant stage manager was there because the stage manager was still in rehearsal for another play when rehearsal started for 'night, Mother. We read through the script once and then we read it again. The second time we read it, we read the other actress's role to better understand what the other character wanted. This helped each of us have compassion for the other character and in turn, the other actress. We tried saying lines in different ways. Sometimes, vocally going up or down at the end of a line, changed the thought behind the line or changed the meaning of the line all together. Rehearsal proved to be the best time to try things differently. I enjoyed thinking about the lines differently and trying them in different ways. Rehearsal gave me the opportunity to work through the characterization that I established for Jessie.

The blocking was not set by the director so Alice and I tried different ideas. Once we got up on our feet, we tried different things with the blocking by walking around without having seen the drawing of the set yet. Once we finally saw the model of the set, 
some of the blocking changed. The blocking continued to change constantly and sometimes it went back and forth. Every time the blocking was complete, there was something new. We occasionally felt that a new prop or another piece of scenery would be needed and would block the scene accordingly, adding the new prop or set piece.

Once we got on the set during tech week, line delivery became a lesser challenge. I now had to keep in mind the notes of the designers. If I was in "the hall," I had to remember not to look through the imaginary wall to talk to Thelma. I had to look in her direction and yell to her because, technically, I was in a different part of the house. Though I forgot a couple of times during rehearsal, I made an effort to remember it during performance. Surprisingly, it was a small detail that some people noticed. Going up and down the stairs to the attic seemed especially tricky to me. I actually did not have a chance to practice it with the actual attic until two days before the performance. I was always a bit nervous, though I never fell. My concern was unfounded when I climbed the stairs because I did it successfully each night of the performance.

Besides the difficulty of mastering the blocking, I also had difficulty mastering memorizing the short answer responses of Jessie. Professor Tompkins, my director, emailed me the summer before the play to tell me to start memorizing my lines. I got this email while I was on a trip with the AATP in South Africa. I had the script with me so I began by learning my monologues. The monologues were short, as well as few and far between. Most of my lines were through dialogue, a discussion between two or more people (in this case two.) Long, uninterrupted speeches were rarely made. I found it particularly hard to start the memorization process with the dialogue because I did not know at this point who would play the mother. My problem was connecting Jessie's full 
thoughts when they were interrupted with the other character's thoughts. Once I returned from my trip, no one could practice with me and the words would not stay in my mind. Borrowing a spoken tape version of the play from the library helped. I began to listen to the tape several times a day and often went to sleep with it playing in the background. Once we started rehearsal, I even recorded Alice and me saying the dialogue of the play on my laptop computer so I could continue to listen to the lines without the tape or other actor. The repetition of hearing the lines over and over helped me to learn the lines because I could hear the response from the other character. My new challenge would be not to imitate the actors on the tape. The words were a major part of the play, so I took a great deal of time perfecting my lines.

I had to work on projecting my lines so that they would be loud enough for everyone in the theater to hear. This was one of the main reasons that I came to graduate school. We spent most of the rehearsal process in a carpeted classroom. I had to learn to vocally account for the larger space of the theater. Often, I would say my lines in my normal speaking voice because everyone in the classroom could hear me. I would have to be reminded by the director that I had to practice speaking loudly now so I could be loud enough in the theater. Though the character may be quiet and depressed, the actress still had to have energy and projection.

I also tried to accent specific words during rehearsal. If I accented the wrong word, the audience would get another message than the one that I needed to get across. I learned some of my lines wrong so the message of the line was not appropriately conveyed. For instance, "I've got you, Mama," implies that Jessie can still count on her mother to give her a reason to live. I often said the line wrong during rehearsal. The 
actual line in the "night, Mother script is; "I've had you, Mama" (24.) The line actually shows that Jessie has had something to live for, but it is not good enough for Jessie to continue living. Accenting "had" not only helped me to remember the line, it also drove the point. These small notes meant that I had to use great strength and power behind each line. Thelma discusses that her friend eats a lot of okra. Jessie responds, "Do you know how much okra Agnes eats?" (29.) Even when we enunciated, some of the audience still wanted to know why Thelma's friend, Agnes, ate Oprah. People are familiar with Oprah Winfrey so we made special effort to pronounce "okra" correctly. Enunciating and stressing lines allows the audience to understand uncommon words.

I also had to prepare myself with the lines so I could know how to build a speech or possibly save my scene partner. If Alice forgot a line, or got choked on some water, or went to the wrong place on stage, I knew the play well enough to get us back on track. Alice was able to help me in moments were I got confused as well. Preparation also meant I would have to pick up line cues internally within a speech and sometimes talk faster. This meant I had an internal monologue that initiated many of the vocal responses that may not seem to be initiated through the dialogue such as the point were Jessie reminisces about her ex-husband, Cecil. Jessie says, "I loved that bridge he built over the creek in the back of the house..."(39.) After Jessie expounds on the magnitude of the bridge, Thelma comments, "He had responsibilities here. He had a wife and son here and he failed you" (40.) Jessie continues with her thought, "Or that baby bed he built for Ricky..." (40.) Jessie has been thinking about all of the immense things Cecil did and hearing Thelma mention Jessie's son reminds Jessie of another great thing that Cecil did for their son, Ricky. Jessie does not address Thelma's statement directly; however, she 
uses it to spur a new thought. Knowing the thought behind the line was the only approach to memorize the material and deliver the lines for the audience to coherently comprehend.

The memorization process also required a great connection with the material. I had to get past words and feel the lines to drive the play by fussing, fighting, and arguing my character's points. Once I got the hang of the lines, they would rapidly spill out of my mouth; I then also had to learn to control my words so that I would not stutter through them, but still attack the material with anger. My director told me that in reality, no one says everything perfectly, but everyone tries to make sure that their point is clearly heard. From time to time, I would still stutter through words, but I learned how to go back and restate my response. I also learned that sitting often sucks the energy from the scene. Though the character sits a lot and has lost her will to live, the personality still had to have energy to engage the audience. Sitting could also be used to punctuate the loss of excitement in Jessie at the end of a line. Finding ways to engage the audience through the words of my character was always a challenge that I enjoyed taking.

I realized during the rehearsal process that I found another challenge that I have always had. It often takes me a while to settle into the character. This is something that I have been working on throughout my tenure as a graduate student. The funny remarks that Jessie makes should be delivered as wit and not as a joke. I knew that Jessie was depressed, but the trick was to realize that she did not easily surrender her status. She is sure of what she wants and she does not sway from her decision. This meant that I had to raise my status at the top of the show so that Jessie's mother could realize soon that Jessie was serious and meant business. I had to be loud and direct and still. Stage business 
lowered the character's status. If Jessie is moving around, then it may look to the audience and to her mother that she is not serious or that she is nervous. The energy must remain, but it had to be channeled so it would seriously read to the audience instead of making light of the subject of suicide.

Coming into this play season, my biggest concern was how the depression and suicidal tendency of Jessie would affect me as Kia. Would I be able to leave the ideas of the play at school and on the stage? My director told me to be prepared for bad dreams and I thought of many of my former colleagues who had experienced sleepless nights when faced with a gritty role. All of these ideas in my head really scared me. I did not want the spirit of a depressed person who longs for death to inhabit me. I did not want to relapse back to the days when I was fighting my own battle with depression.

I started to fight, instead, the truth of the character. Early in the rehearsal process, I felt like it was easier to pretend to be upset, or crazy, or mad instead of actually feeling the emotion. My director instantly "called me out" on indicating instead of believing in the moment. Indicating is a bad ploy used by actors who attempt to show the emotion instead of feeling the emotion and allowing the audience to see the feelings on their own. The more I thought about the character, the lines, and the set of given circumstances laid out for the character by the playwright, the more connected to Jessie I felt. When I tried to do the role without worrying about turning into the person Jessie was, the more I connected with the character and empathized with her. I realized that I did not have to agree with all Jessie said and did to identify with how she felt.

Understanding the character better did not create a depression within me or cause me to have terrible nightmares about my suicide. Understanding the character allowed 
me to be in sync with people who have the same issues that bothered Jessie. I began to notice people around me who had the same symptoms that plagued Jessie: belittlement by parents, the loss of a love, and the hiding of a mental disorder all fell in the midst of my "depression radar." I did have a bad dream about suicide, though it was the suicide of a friend. I tried not to let this dream affect my performance, though I became more empathetic to Jessie and her views when I considered that someone who was close to me may be dealing with the same issues as Jessie.

The rehearsal process afforded me the opportunity of dealing with blocking, projecting, memorization, and enunciation challenges, and status and characterization issues. After delving into rehearsal and finding out many things about the character, I was very confident about performing. Now that rehearsal was finished, I was excided to start the performance process. 


\section{CHAPTER V}

\section{PERFORMANCE - Facing an altered reality}

Over the course of three months of rehearsal, I felt confident going into the performances. I remarked to my director several times that this was the most comfortable I had ever felt before an opening night. Rehearsing for three months gave me major confidence for the performance. I felt like I could have opened the show two weeks before the opening. Having so much time to focus was a wonderful experience for me. Often, in educational theater, we are pushing deadlines and also dealing with school work and sometimes outside jobs. Each performance would grant me the chance to know more about myself as an actress and what I have learned as an acting student.

Most of the crew that saw the performance in rehearsal and during the week of technical rehearsals all remarked about how well the play went. These performances gave me a perception of making theater. The audiences fed the performances, and when the performers were connected, we fed the audience. I was a bit concerned after the last technical rehearsal. We had made it through the entire show and then silence. There was no applause at the end of the play when the lights faded to a blackout. One person in the props crew came to me after the rehearsal and said, "Be advised." My heart sank during

the pause. He then smiled and said, "You rock." I was elated because this member of the crew was also one of the better actors in the department and he is always direct and honest. 
I realized this was not a play in which I could judge the audience's appreciation of the play by their reaction while I was on stage. Sometimes audiences would laugh loudly, sometimes I could hear sighs of distress or understanding, and sometimes I only heard dead silence (no pun intended.) Often, after a particularly quiet audience, we would receive a standing ovation.

Most people told me that they knew instantly that there was something seriously wrong with Jessie, "She seemed crazy." I interpret this statement as an acknowledgement that audience members recognized my acting goal and I executed my delivery successfully. My characterization of Jessie was that she was confident and matter of fact, there were no highs or lows to Jessie's attitude in the beginning of the play. After much probing from my director, I was able to find the place in myself that was strong enough to tell Thelma Jessie's plans in a stern manner.

Jessie had thought of this night for a long time and planned everything that she wanted to say to her mother. It was not until Jessie unsuspectingly learned some things, that she lost her sense of her goal, and became upset. Jessie became particularly upset this night when she discovered from her mother that Cecil, her ex-husband, had cheated on her. Though Jessie's words were planned, each night was new and theater exists for each performance as if the action is happening for the first time, so it was necessary not to anticipate lines from the mother.

Opening night was a Wednesday and I was ecstatic to start the run. That night, I would start a ritual that I repeated before each performance. I did a vocal warm-up that I learned in Dr. Frye's voice class. It included some meditation, facial message, voice drills, physical stretch and exercise. I did scales with my voice and spoke my lines by 
using my diaphragm as the source of power behind my voice. This was a way for me to work to eliminate my habit of pushing my voice from my throat. Using my "throatvoice" often was the result of excitement or nerves. Though, I mainly ran on adrenalin that night, I still kept a strong, full, natural voice. I still knew that there was room for improvement throughout the run of the show.

Professor Tompkins, my director, seemed pleased, but did not resist giving me another note. He reminded me not to rush the ending. Jessie almost slides back into her original mood and she knows that she must carry out her suicide. She cannot become too sentimental in her concern for her mother's grief, she must remain strong. Thelma, Jessie's mother, emotionally breaks down when she realizes that her only daughter, Jessie, will die tonight. Jessie is torn between staying with Thelma and leaving Thelma to take care of herself. I took the note and remembered not to show any overt emotion at the end of the play. This helped in allowing the audience the time and opportunity to wonder if the gun would really fire after Jessie went into her bedroom.

Thursday night, I felt the energy in the audience. I could hear their sounds of laughter and groans of empathy, their verbal cues gave me energy. I was assured in my performance. As a performer, gauging the audience is difficult. You are told in acting classes not to expect anything from the audience, but they are a major part of the production. The Enjoyment of Theater states the traits of theater are:

- Movement through time

- Doers ("performers")

- Watchers ("audiences")

- A place of performance ("stage" or "theatre) (7.)

The comfort I received for the audience contributed to my natural reaction on stage. At one point toward the end of the play, Alice got choked. We were at the kitchen counter, 
and I knew that Alice's character was too upset to move. Though it was not blocked, it was my responsibility to help her by giving her a drink of water. I considered pouring her a glass of water from the tap; then, I remembered being warned that the tap-water was not fit for consumption. As I contemplated another option, my eyes scanned the stage and I saw a glass of water on the coffee table that Alice had started drinking at the beginning of the play. Getting up to get the water for Alice is a great example of the ability to react to the moment. I learned this ability in rehearsal and I would use it again before the end of the run of the show.

Friday night seemed to be the least connected performance of all. Alice had taken some cold medicine and was sleepy. I had just awakened from a nap and was fighting to maintain the little energy I had. I knew how I felt early in the run, so I tried to work through the performance and I only made things worse by trying too hard. Finally, I forgot about the issues that seemed to be slowing the performance down. I decided to let go of that type of analysis and dive into the character. I realized that I had let my thought process interfere with the presentation because I was not connected. I was Kia and not Jessie. The mental, physical, and spiritual process of finding a character is the purpose of the rehearsal process. During the performance is when all of the technique should be put aside so that the character can live through the actor. This reinstated that art is subjective; just when we were unimpressed with our own performance, the audience loved it.

Just the opposite happened on Saturday night, the performance was almost effortless and I felt almost that the character, Jessie, was playing me instead of me playing the character. I used my ability to react again that night when one of the clocks fell down during a heated debate between Thelma and Jessie. As Jessie, the primary 
caretaker of the house, I picked up the clock and continued the scene. We were both proud of our performances that night. However, there was not much applause or response. Once Alice and I left the theater after the curtain call, I saw many tissues dabbing crying eyes. After she returned from the restroom where she went to calm down, one theater student told me that the restroom was packed with women fixing their makeup. One could deduce that the audience was truly emotionally touched.

Performing two shows on Sunday would require a huge amount of energy. It was important for me to attend the early church service to find and maintain my own energy for the two shows. I had been worried about the matinee because some people said that the audiences give no energy during that performance. The audience sold out for this show and we had a ten-minute hold before the performance started. A few of them settled into their seats for a nap. Some seemed bored to tears and others seemed audibly moved to tears. The excitement of this heightened situation drove my performance. I fed into giving the ones that wanted to be there something for their money while I worked to get interest from the disinterested. Though this was not my best performance, I enjoyed it the most because I worked to engage the audience.

I planned to enjoy the closing performance because it would possibly be my last at this institution. I was advancing the story of this troubled young woman. I was intensely aware of this last audience. I went through the performance outside of myself. It seemed like a great dream that this show was performed and ended with more accolades and it felt good! I did not consider the grandness of my accomplishment until the middle of the strike. For in theater, the strike is the process of taking apart the set after the play. The actors at the University of Louisville are required to assist in this 
process. After the crew had literally taken everything but the kitchen sink, I realized that the whole thing was over. Though it felt good for the performance to be complete, I felt a bit of sadness. This performance run, with this cast and crew would never be duplicated anywhere, ever again.

Performing this role permitted me a better understanding of the interaction between actor and audience. I could take the knowledge that I learned in acting, movement, and voice classes and apply it to the stage. I used my research and characterization gained before and during rehearsal to inform the portrayal of Jessie for audiences. After finding a thesis role, doing research to empathize with the character, and rehearsing to have a substantial grasp of the material, I was best prepared to have a successful performance. After I had completed all of the elements of creating the character of Jessie, I was then able to draw a clear conclusion of my entire experience at $\mathrm{U}$ of $\mathrm{L}$. 


\section{CHAPTER VI \\ CONCLUSION - Drying the tears}

The tracks of my tears led to a smile on my face when I realized that I am the master of my own fate and I am the captain of my soul. My experience at the University of Louisville had really saddened me, beat me, hurt me, and confused me, but it had not broken me down. This process of gaining a post-baccalaureate degree and finding myself had also enlightened me, excited me, toughened me, and given me a new lease on life and my chosen profession. Though I am proud of who I have become, I totally disagree with the evaluation methods of this theater department. I do not believe that you have to humiliate students to grant them the opportunity to grow and become better actors. The faculty questioning my talent eventually led to me questioning myself. Performing in 'night, Mother afforded me an opportunity to gain confidence in my skill and become proud of my work as an actor.

I learned from the process of mounting the play, 'night, Mother that I can carry a show and carry it well. I was able to find a deeper part to this character. This play gave me the chance I had never had. Now, I could reach inside myself and find another character.

Though I felt that I found the physical state of Jessie, I know that there are other types of characters that would be more of a challenge for me physically. I am still not as graceful or rhythmic as I should be as an actress. Professor Tompkins' movement classes 
continue to show me how much my body is capable of as I take yoga, Pilates, and cardiovascular aerobic exercise classes. Professor Tompkins helped me find grace by exploring flowing motions when he taught Elizabethan dance in our Shakespeare class. I gained a new sense of creativity from my modern dance class that until then, did not know how to express with my body. Even the jazz workshops that Professor Burton coordinated allowed me to feel a rhythm and find it with my movements. From the aforementioned classes, I used concepts to find movements for Jessie. Specifically, I could quickly move about the house while I was cleaning, and yet speak slowly. I also could find ways for Jessie to sit and stand and even get on the ground.

After finding her movements, I worked hard to find Jessie's voice and I think I came to a good vocal state, though I know that voice is still a factor in my acting. I am still working to incorporate vocal warm-ups before a performance to provide the optimal voice of the character. I was able to stay conscious of my voice during rehearsals. I made a conscious effort not to allow Alice's high voice to disrupt my voice from its middle range by doing the daily vocal warm-ups that I learned in voice class. I became more cognizant of the differences in Alice and my voices by listening to her speech and locating my mid-range voice from my diaphragm. Our different voices (high and midrange) seemed to bring a sense of variety to the performance.

I learned from my matriculation at the University of Louisville not take myself so seriously. Moreover, I learned not to take others (especially those in authority) too seriously. I have always been humble and respectful, but I know now that I should expect respect from others, and if it is not given, demand it. When I have respect from others, I feel better about myself and others seemed to be more apt to want to respect me. 
When I came here, I was concerned about what the faculty thought of me. It did not matter if they liked me, it only mattered that they respected me as an actress, as a student, and mainly as a person. I think that respect is shown with honesty at all times, and not just when criticism is solicited. I had heard many horror stories about former students who felt as if they had been treated unfairly when being evaluated by the faculty (especially the Black students.) I instantly knew that I had to mind my $p$ 's and $q$ 's. I thought that I could avoid the wrath of the faculty by laying low and staying quiet.

I got through a whole year by staying quiet and I even enjoyed my first year. Then, in my second year, it seemed like the faculty just got bored and needed someone to antagonize. By then, the whole third year acting class was African American and all of that class had at least one negative experience with the faculty. The first year students were still under the delusion that they were immune to the faculty's misuse of power. I am the only African American in my class and my advisor just happened to have been on sabbatical when I was scorned by the faculty about my performances. I felt like I was the obvious choice to be pressured.

I got past the pressure and learned not to dwell on what others thought. This realization instituted an improvement in my self-esteem. Toward the end of my last semester in graduate school, I was asked to portray Lady in Brown in Ntozake Shange's for colored girls who have considered suicide/ when the rainbow is enuf (for colored girls.) When I found out that the other African American graduate students planned to mount a studio show of this production, I had been a bit disappointed that I was not invited to participate. 
I had learned long ago (thanks to this department) not to let casting bother me. As an actress, you must be mentally prepared to move on if you do not receive the role you desire. However, once another actress left the department because of her own bout with its stresses, her role was offered to me. I learned I was not on the list of possible actresses because I was in the process of writing a thesis, not because I was unqualified.

I was thrilled to have this opportunity, though I regret that it was late in my $U$ of L career. This play about African American women, the life stresses they encounter, and how their stresses may result in suicide, was the perfect way to end my tenure here. This play would help me bring everything back to why this thesis started. This was a choreopoem that interwove the same subjects of my thesis, both the production and the paper.

for colored girls was also the last play I performed in my undergraduate career. Then, I was Lady in Purple. Dr. Tonea Stewart, chairperson of the Theater program at Alabama State University, was our director. Once again, I knew that this production would close the circle of my scholastic career. Not only would one of Dr. Stewart's protégé's, Brain Martin, direct this show, but there were several other actresses in this production who had been in one of Dr. Stewart's other productions of for colored girls. Brian Martin decided to split the character of Lady in Purple between two undergraduate students. One of the other actresses in this production had also been Lady in Purple in a previous production. All of these circumstances allowed me to see other interpretations of something I had done that was close to me. I am still learning so much about what I am capable of doing on stage. I am proud of the accomplishments I have made as an actress at $\mathrm{U}$ of $\mathrm{L}$. The confidence $\mathrm{I}$ have found is amazing. I felt good about this 
performance and I still have the capacity not to care what the faculty thinks about my performance because it is not even being graded.

This play would help me strive for more physical fluidity and confidence.

Madam Diallo teaches African dance at $\mathrm{U}$ of $\mathrm{L}$ and choreographed a dance piece in for colored girls. Interestingly, I was able to learn the routine quickly, without major problems. My director wanted a passionate, intense, and insightful character that still moved with zeal. I knew instantly that the Lady in Brown needed a rich, deep voice. Dr. Frye has been working with me in class to exert more vocal power from a lower register than I have normally been using. I can now become the successful, professional actress I always wanted because as all of the characters say at the end of for colored girls, " $\mathrm{i}$ found god in myself \& i loved her/ I loved her fiercely" ( 63.)

Cicely Tyson, my acting icon, was the keynote speaker at the AATP's tenth anniversary gala. Before her speech, she opened the floor for questions. I took this occasion to tell her what an influence she had made on my life when I was ten years-old, in the fifth grade. I partially credited her with my decision to obtain degrees in Theater Arts. Once again, Ms. Tyson's presence was a great way for me to close this chapter in my life. Seeing her again was a completion of the task she gave me and concluded the circle of that part of my life.

I know that as a professional actor, one should only to be in a few places in the United States to actively pursue it. I feel I have been adequately prepared to work in this industry and now: "there ain't nothin' to it, but to do it." I have the confidence and I learned it here. Now, I must move on and shine in this industry. I plan to move to Los 
Angeles the summer after I graduate with my Master of Fine Arts degree from the University of Louisville. Now it is time for me to start the next chapter of my life. 


\section{REFERENCES}

Bruder, Melissa, Colhn; Lee Michael, Olnek; Pollack, Madeleine; Nathaniel; Previto, Robert; Zigler, Scott. A Practical Handbook for the Actor. New York: Random House, 1986.

Cameron, Kenneth M. and Gillespie, Patti P. The Enjoyment of Theatre. $5^{\text {th }}$ ed. Needham Heights, MA: Macmillan, 2000.

C.L.I.M.B. Theater Company. St. Paul, MN. 1pp. 30 Dec. $2003<$ http://www.climb.org>.

Cohen, Robert. Acting One. $2^{\text {nd }}$ ed. Mountain View, California: Mayfield, 1991.

Freeman, John M., M.D.; Vining, Eileen P.G., M.D. and Pillas, Diana J, M.D. Seizures and Epilepsy in Childhood: a Guide for Parents. $2^{\text {nd }}$ ed. Baltimore: Johns Hopkins University Press, 1993.

Green, Blake. "Feeling 'Blue' / Playwright speaks ill, and well of her new show." Newsday 1 Dec 1999.

The Holy Bible, New International Standard Version. Grand Rapids, MI: Zondervan Publishing House. 1995.

Kerkhoff, Ingrid. "Marsha Norman," Bergen Record Corp. 1995. 23 pp. Contemporary American Drama. 26 Jan. $2004<$ http://www.fb10.unibremen.de/anglistik/kerkhoff/ContempDrama/Norman.htm>.

Leften, Lester A. Psychology. $5^{\text {th }}$ ed. Needham Heights, MA: Paramount, 1994.

Norman, Marsha. 'night, Mother. New York: Dramatists Play Service, Inc. 1983.

Shange, Ntozake. for colored girls who have considered suicide/ when the rainbow is enuf. New York: Simon \& Schuster. 1977.

"Suicide Among Blacks." HealthyPlace.com, Inc. 2000-2003. 2 pp. 5 Apr. 2004. $<$ http://www.healthyplace.com/communities/depression/minorities 5.asp>.

"Teens, Race and Stress." CBSNEWS.com. AP. Washington. 30 Oct. 2003. 2 pp. 5 Apr. 2004. <http://www.cbsnews.com/stories/2003/10/30/health/main581068.shtml>. 
Wesley, Joya. "Depression.” Black Women's Health.com. Greensboro, NC. 2003. $<\mathrm{http}: / /$ www.blackwomenshealth.com/depression.htm>. 


\section{CURRICULUM VITAE}

NAME: $\quad$ Kia Fisher

ADDRESS: $\quad$ Department of Theater Arts

University of Louisville

Louisville, Kentucky 40292

EDUCATION $\quad$ B.A., Theatre Arts

\& TRAINING: Clark Atlanta University

1996-2000

M.F.A., Theatre Arts - Performance

University of Louisville

2001-2004

AWARDS

\& HONORS:

Best Performance in the Theater Arts Department

Clark Atlanta University

2000

Miss CAU Players

1999-2000

Magna cum laude

Clark Atlanta University

2000

PROFESSIONAL Lambda Pi Eta

SOCIETIES: Communications Honor Society

PUBLICATIONS: Orientation Magazine

Fall 2002

INVITED U of L Theater Arts Town Hall

PRESENTATIONS: Issues in Israel 2002

South Africa Trip 2003

U of L Wesley Foundation

Issues in Israel 2002 